\title{
Peran Sukuk Surat Berharga Syariah Negara (SBSN) dalam Pertumbuhan Pembangunan Ekonomi Indonesia
}

\author{
Siti Latifah \\ Prodi Magister Ekonomi Syariah, IAIN Kudus \\ *Email korespondensi: sitilatifah1619@gmail.com
}

Abstract

Indonesia has enormous potential in developing Islamic finance because Indonesia has the largest number of Muslims in the world and high economic growth. The issuance of State Sharia Securities (sukuk) has become the main financing instrument. The presence of sukuk further strengthens the government's ability to finance the budget deficit. The government has many choices in determining the combination of its financing instruments. The government can keep debt costs to a minimum. This study aims to determine 1) the development of sukuk in Indonesia and 2) the role of sukuk in Indonesia's economic growth. This research uses qualitative methods and library research approach. Researchers use secondary data, namely data sourced from existing literature or references. The results of this study are 1) The Indonesian government has issued Retail Sukuk (SR), namely SR 001 - SR 013. The issuance of State Sukuk from year to year continues to increase, in accordance with developments and strategies applied in the APBN. 2) The role of State Sukuk has a very positive impact, such as financing project development, encouraging development of the Islamic financial market, creating branch marks in the Islamic financial market, developing alternative investment instruments, and utilizing public funds.

Keywords: Sukuk, Government, Economic, Sharia

Saran Sitasi: Latifah, S. (2020). Peran Sukuk Surat Berharga Syariah Negara (SBSN) dalam Pertumbuhan Pembangunan Ekonomi Indonesia. Jurnal Ilmiah Ekonomi Islam, 6(03), 421-427. doi:http://dx.doi.org/10.29040/jiei.v6i3.1369

DOI: http://dx.doi.org/10.29040/jiei.v6i3.1369

\section{PENDAHULUAN}

Global Islamic Finance Report 2018 melaporkan bahwa Indonesia memiliki potensi luar biasa untuk mengembangkan keuangan syariah. Karena Indonesia didukung oleh jumlah penduduk Muslim terbesar di dunia, bonus demografi, kelas menengah yang besar, ekonomi terbesar di antara negara Muslim, pertumbuhan ekonomi tinggi, dan penetrasi keuangan syariah yang masih relatif rendah (Elba Damhuri, 2018).

Pengembangan berbagai alternatif instrumen pembiayaan anggaran negara, khususnya instrumen pembiayaan yang berdasarkan prinsip syariah guna memobilisasi dana publik secara luas telah dilaksanakan oleh pemerintah. Instrumen keuangan yang diterbitkan sesuai dengan prinsip-prinsip syariah, memberikan kepastian hukum, transparan, dan akuntabel.

Salah satu bentuk instrumen keuangan syariah yang telah banyak diterbitkan baik oleh Korporasi maupun negara adalah surat berharga berdasarkan prinsip syariah, atau secara internasional dikenal dengan istilah Sukuk. Instrumen keuangan syariah ini berbeda dengan surat berharga konvensional. Perbedaan yang prinsip antara lain surat berharga berdasarkan prinsip syariah menggunakan konsep Imbalan bukan bunga sebagaimana dikenal dalam instrumen keuangan konvensional dan diperlukannya sejumlah tertentu aset yang digunakan sebagai dasar untuk melakukan transaksi dengan menggunakan Akad berdasarkan prinsip syariah.(Presiden Republik Indonesia, 2008)

Penerbitan SBSN saat ini telah menjadi instrumen pembiayaan utama, selain instrumen pembiayaan yang telah ada sebelumnya yaitu Surat Utang Negara dan pinjaman langsung. Keberadaan SBSN tidak tumpang tindih dengan instrumen pembiayaan lainnya, meskipun SBSN instrumen baru. Justru SBSN semakin memperkuat kemampuan pemerintah dalam membiayai defisit anggarannya. 


\section{Jurnal Ilmiah Ekonomi Islam, 6(03), 2020, 422}

Pemerintah mempunyai banyak pilihan dalam menentukan kombinasi instrumen pembiayaannya sehingga pemerintah dapat mengupayakan biaya utang seminimal mungkin.

Indonesia adalah negara berpenduduk Muslim terbesar di dunia, maka dapat dipastikan bahwa instrumen-instrumen syariah akan laris di pasar modal Indonesia, termasuk obligasi syariah (sukuk). Obligasi syariah merupakan instrumen yang paling ampuh menarik investor dari Timur Tengah. Seperti diketahui bahwa investor Timur Tengah lebih suka memilih obligasi syariah (sukuk) untuk menanamkan modalnya. Baik di dunia internasional maupun ditingkat nasional. Instrumen ini tumbuh pesat seiring dengan pertumbuhan dan perkembangan instrumen keuangan konvensional lainnya. (Sunarsih, 2008)

Penerbitan Sukuk Tabungan menggunakan struktur akad Wakalah. Dana hasil penerbitan akan digunakan untuk kegiatan investasi berupa pembelian hak manfaat Barang Milik Negara untuk disewakan kepada pemerintah, serta pengadaan proyek untuk disewakan kepada pemerintah. Imbalan berasal dari keuntungan hasil kegiatan investasi tersebut.

Hasil penelitian terdahulu telah dilakukan oleh Erma Sri Hastuti yang berjudul Sukuk Tabungan: Investasi Syariah Pendorong Pembangunan Ekonomi Inklusif menghasilkan bahwa sukuk tabungan telah membantu pemerintah dalam pembangunan dan penerbitan sukuk tabungan memiliki beberapa risiko seperti risiko likuiditas tapi dengan manajemen yang baik akan mencegah adanya likuidity risk. Penelitian ini juga menyatakan bahwa belum banyak masyarakat yang mengenal sukuk tabungan sehingga perlu adanya sosialisasi dan edukasi tentang sukuk tabungan kepada masyarakat umum (Hastuti, 2018).

Penelitian lain mengenai sukuk juga dilakukan oleh Angrum Pratiwi yang berjudul Peran Sukuk Negara dalam Pembiayaan Infrastruktur. Dalam hasil penelitiannya menyebutkan bahwa ada enam sasaran utama infrastruktur yang akan dan telah dibangun dari anggaran tahun 2017 ini, enam infrastruktur tersebut adalah: 1) Pembangunan jalan sepanjang 836 kilometer, 2) Pembangunan jembatan sepanjang 10.198 meter, 3) Pembangunan 13 bandar udara (bandara) baru maupun lanjutan, 4) Pembangunan dan pengembangan fasilitas pelabuhan laut di 61 lokasi yang tersebar di seluruh Indonesia, 5) Pembangunan jalur kereta api tahap I dan lanjutan sepanjang 710 kilometer spoor, 6) Pembangunan terminal penumpang lanjutan di 3 lokasi. Berdasarkan uraian tersebut, peningkatan pembiayaan infrastruktur berbasis sukuk mengalami peningkatan sejak tahun 2013. Hal ini menunjukkan bahwa sukuk ternyata menjadi instrumen keuangan yang penting diterapkan dalam pembangunan infrastruktur (Ramadayanti et al., 2018).

Hadi Peristiwo juga telah melakukan penelitian yang berjudul Analisis Minat Investor di Kota Serang terhadap Investasi Syariah pada Pasar Modal Syariah. Hasil penelitiannya menyatakan bahwa terdapat 2 (dua) faktor yang paling menentukan (signifikan) terhadap minat investor untuk berinvestasi syariah. Pertama adalah kehalalan terhadap imbal hasil yang akan diperoleh dalam berinvestasi efek-efek syariah. Kedua adalah keyakinan bahwa efek syariah tidak bertentangan dengan prinsip syariah. Berdasarkan atas hasil serta analisis kajian penelitian yang telah dilakukan maka dapat disimpulkan bahwa sebagian besar investor di Kota Serang berminat untuk berinvestasi syariah pada pasar modal syariah (Peristiwo, 2016).

Peneliti lain, Anik, juga telah meneliti tentang Pengembangan Instrumen Sukuk dalam Medukung Pembangunan Infratruktur yang menghasilkan bahwa proses perencanaan pengembangan sukuk dengan topdown dan bottom-up bertujuan menyelaraskan program-program untuk menjamin adanya sinergi/konvergensi dari semua kegiatan pemerintah dan masyarakat dalam optimalisasi pengembangan sukuk. Strategi perencanaan secara Top-Down adalah penerbitan "Sukuk Wakaf" sebagai Upaya Peningkatan Market Share Sukuk. Sebagai produk baru, sukuk wakaf masih menghadapi beberapa kendala. Diantaranya dibutuhkan peraturan yang jelas dan khusus mengatur tentang sukuk wakaf. Serta Membuat landasan syariah tentang penerbitan sukuk wakaf. Strategi kedua adalah membentuk Tim APS (Akselerasi Pengembangan Sukuk). Tim ini sebagai wadah atau organisasi yang dibentuk untuk mengakomodir percepatan dan pertumbuhan obligasi syariah atau sukuk.Sedangkan strategi perencanaan secara Top-Down adalah membentuk forum EKPPOS (Edukasi, Komunikasi, Pemasaran dan Pengembangan Obligasi Syariah). Strategi kedua adalah memberikan praktikum Pasar Modal Syariah di lingkungan kampus (Anik \& Prastiwi, 2017).

Penelitian ini berbeda dengan hasil penelitian terdahulu yang telah dilakukan oleh peneliti-peneliti sebelumnya. Penelitian ini berfokus kepada peran sukuk dalam pertumbuhan ekonomi Indonesia 


\section{Jurnal Ilmiah Ekonomi Islam, 6(03), 2020, 423}

sedangkan penelitian sebelumnya rata-rata fokus pada topik pertumbuhan infrastruktur. Oleh karena itu, penelitian ini bertujuan untuk mengetahui 1) perkembangan sukuk Surat Berharga Syariah Negara (SBSN) di Indonesia dan 2) Peran Sukuk Surat Berharga Syariah Negara (SBSN) dalam Pertumbuhan Ekonomi Indonesia.

\section{METODE PENELITIAN}

Metode penelitian yang digunakan adalah metode kualitatif dengan pendekatan studi kepustakaan (library research). Studi kepustakaan yaitu metode yang mencari referensi yang relevan dengan permasalahan yang ditemukan. Studi kepustakaan menggambarkan analisis teoritis, kajian ilmiah, rujukan serta literatur yang berhubungan dengan kebiasaan masyarakat setempat, norma dan nilai yang terbangun pada kondisi lapangan yang diamati (Sugiyono, 2016). Selain itu, studi kepustakaan juga dapat mempelajari berbagai buku referensi serta hasil penelitian sebelumnya yang sejenis yang berguna untuk mendapatkan landasan teori mengenai masalah yang akan diteliti (Sarwono, 2010).

Adapun data yang digunakan adalah data sekunder, yaitu data yang bersumber dari literatur atau referensi yang ada, seperti yang termuat dalam jurnal dan makalah ilmiah, ensiklopedia, literatur, serta sumber data lain yang berkaitan dengan topik penelitian. Teknik analisis dalam penelitian ini menggunakan teknik dimana studi-studi sumber data dipelajari sehingga menghasilkan kesimpulan yang aktual sesuai dengan topik penelitian.

\section{PEMBAHASAN}

\subsection{Perkembangan Sukuk Surat Berharga Syariah Negara (SBSN) di Indonesia}

Istilah sukuk sesungguhnya telah dikenal sejak abad pertengahan, di mana umat Islam menggunakan term sukuk dalam konteks perdagangan internasional. Sukuk merupakan bentuk jamak dari kata sakk. Sukuk dipergunakan oleh para pedagang pada masa itu sebagai dokumen yang menunjukkan kewajiban finansial yang timbul dari usaha perdagangan dan aktivitas komersial lainnya. Namun demikian, sejumlah penulis Barat yang memiliki concern terhadap sejarah Islam dan bangsa Arab, menyatakan bahwa sakk inilah yang menjadi akar kata "cheque" dalam bahasa latin, yang saat ini telah menjadi sesuatu yang lazim dipergunakan dalam transaksi dunia perbankan kontemporer (Beik, 2011).

Kata sukuk berasal dari bahasa Arab shukûk, bentuk jamak dari kata sakk, yang dalam peristilahan ekonomi berarti legal instrument, deed, atau check (Sudarsono, 2009). Sukuk merupakan instrumen yang di perdagangkan di bursa efek syariah. Menurut Undang-Undang Surat Berharga Syariah Negara (SBSN) sukuk adalah surat berharga yang diterbitkan berdasarkan prinsip syariah, sebagai bukti atas bagian penyertaan terhadap aset SBSN, baik dalam mata uang rupiah maupun valuta asing. Pihak yang menerbitkan sukuk negara adalah badan hukum yang didirikan berdasarkan ketentuan undang-undang untuk menerbitkan sukuk. Asetnya adalah barang milik negara yang memiliki nilai ekonomis yang dijadikan sebagai dasar penerbitan sukuk Negara (Presiden Republik Indonesia, 2008).

Secara umum, sukuk adalah kekayaan pendukung pendapatan yang stabil, dapat diperdagangkan dan sertifikat kepercayaan yang sesuai dengan syariah (Naili Rahmawati, 2015). Kondisi utama mengapa sukuk ini dikeluarkan adalah sebagai penyeimbang dari kekayaan yang terdapat dalam neraca keuangan pemerintah, penguasa moneter, perusahaan, bank, dan lembaga keuangan serta bentuk entitas lainnya yang memobilisasi dana masyarakat. Emiten atau pihak yang menerbitkan sukuk dapat berasal dari institusi pemerintah, perusahaan swasta, lembaga keuangan, maupun otoritas moneter (Umam, 2013).

Kehadiran sukuk di Indonesia cenderung lambat jika dibandingkan dengan Negara-negara yang memiliki penduduk mayoritas Islam lainnya, seperti Malaysia, Bahrain, dan Sudan. Sukuk yang pertama terbit di Indonesia adalah sukuk korporat, diterbitkan oleh PT.Indosat, Tbk pada tahun 2002 dengan nilai Rp 175 milliar menggunakan akad mudharabah. Kemudian diikuti oleh korporasi lain. Sukuk Negara terbit pada tahun 2008, setelah keluarnya undangundang no.19 tahun 2008 yang mengatur tentang Surat Berharga Syariah Negara (SBSN). Menurut fatwa DSN-MUI nomor 32/DSN-MUI/IX/2002, terdapat 6 akad sukuk yang berlaku di Indonesia saat ini: Mudharabah, Musyarakah, Murabahah, Salam, Istishna dan Ijarah. Disamping itu DSAK-IAI juga telah menerbitkan kerangka dasar penyusunan penyajian laporan keuangan syariah yaitu PSAK NO.101 tentang penyajian laporan keuangan syariah dan PSAK NO.105 tentang akuntansi mudharabah. 


\section{Jurnal Ilmiah Ekonomi Islam, 6(03), 2020, 424}

Oleh karena itu, diharapkan produk sukuk tidak hanya sebagai instrument investasi yang lebih Islami dan lebih likuid, namun peraturan dan perundangundangan yang saat ini telah dan sedang dirumuskan juga mampu menjadikan Sukuk memiliki daya saing dan daya banding dengan obligasi konvensional. Di Indonesia sendiri pemerintah telah mengeluarkan Sukuk Ritel (SR) yaitu SR 001, SR 002, SR 003, SR 004, SR 005, SR 006, SR 007, SR 008, SR 009, SR 010, SR 011, SR 012, dan SR 013 (Direktorat Jenderal et al., n.d.).

Implementasi kebijakan penerbitan Sukuk Negara sebagai intrumen pembiayaan defisit APBN dengan diterbitkannya Sukuk Negara seri Ijarah Fixed Rate (IFR) 001 senilai Rp2,71 triliun dan seri IFR 002 senilai Rp1,98 triliun. Penerbitan Sukuk Negara dari tahun ke tahun terus mengalami peningkatan, sesuai dengan perkembangan dan strategi yang diterapkan dalam APBN. Seiring dengan tugas dalam memenuhi pembiayaan defisit APBN yang terus meningkat, Pemerintah terus melakukan pengembangan instrumen SBSN (Ramadayanti et al., 2018).

\subsection{Peran Sukuk Surat Berharga Syariah Negara (SBSN) dalam Pertumbuhan Ekonomi Indonesia}

Tujuan pemerintah menerbitkan Sukuk Negara adalah untuk membiayai APBN, termasuk membiayai pembangunan proyek. Sebagaimana disebutkan pada pasal 4 UU SBSN bahwa tujuan SBSN diterbitkan adalah untuk membiayai Anggaran Pendapatan dan Belanja Negara termasuk membiayai pembangunan proyek. Proyek yang dapat dibiayai dengan sukuk negara adalah sektor energi, telekomunikasi, perhubungan, pertanian, industri manufaktur, dan perumahan. Selain itu juga untuk memperluas basis sumber pembiayaan anggaran negara atau perusahaan, mendorong pengembangan pasar keuangan syariah, menciptakan benchmark di pasar keuangan syariah, diversifikasi basis investor, mengembangkan alternatif instrumen investasi, mengoptimalkan pemanfaatan barang milik negara atau perusahaan, dan memanfaatkan dana-dana masyarakat yang belum terjaring oleh sistem obligasi dan perbankan konvensional.

Penerbitan Sukuk Negara juga mempunyai fungsi strategis lainnya atau dampak positif dari penerbitan Sukuk Negara, beberapa dampak strategis diantaranya adalah: a. Mendorong pertumbuhan industri keuangan syariah nasional

Beberapa peneliti telah mengemukakan relevansi penerbitan SBSN dengan perkembangan industri keuangan syariah. Azwar mengemukakan bahwa kepemilikan sukuk negara domestik pada perbankan syariah sebagai bagian penyediaan aset yang aman bagi perbankan syariah berpengaruh positif dan signifikan terhadap rasio nilai total pembiayaan perbankan syariah terhadap GDP yang mengukur perkembangan perbankan syariah (Iskandar, 2014). Tersedianya SBSN menjadi alternatif investasi bagi industri keuangan syariah yang mengalami ekses likuiditas maupun ingin mengambangkan aset melalui SBSN. Selain itu, untuk keperluan mengatur likuiditas industri keuangan syariah dapat memperjualbelikan SBSN sesuai dengan kebutuhan. Telah tersedia berbagai tenor SBSN, baik jangka pendek (tenor 6 bulan) sampai dengan tenor panjang (diatas 10 tahun). Tersedianya diversifikasi tenor tersebut memberikan kemudahan bagi industri dalam mengatur portofolio investasinya.

b. Meningkatkan porsi pembiayaan infrastruktur APBN

Penerbitan seri-seri Sukuk Negara yang menggunakan underlying asset berupa proyek infrastruktur telah bertambah luasnya ruang fiskal APBN. Pendanaan pembangunan infrastruktur yang seharusnya berada pada pos Belanja Negara ditarik sebagian ke pos Pembiayaan. Hal ini menambah ruang di pos Belanja Negara untuk dimanfaatkan dalam pembiayaan infrastruktur lainnya. Dengan begitu, dalam satu tahun anggaran akan semakin banyak proyek Pemerintah yang dapat dibiayai baik dari pos Belanja maupun Pembiayaan. Dimasa yang akan datang, Pemerintah berencana agar penerbitan SBSN lebih difokuskan untuk pembangunan infrastruktur. Seiring dengan kemajuan ekonomi masyarakat, maka kemampuan masyarakat dalam menyerap penerbitan SBSN juga akan semakin meningkat. Pemanfaatan penerbitan SBSN untuk pembangunan infrastruktur juga mempunyai arti memberikan kesempatan yang luas kepada masyarakat untuk ikut membantu pembangunan bangsa. 


\section{Jurnal Ilmiah Ekonomi Islam, 6(03), 2020, 425}

c. Mendorong tertib pengelolaan BMN

Perlunya penyediaan underlying asset dalam penerbitan SBSN dalam bentuk BMN telah mendorong tertib administrasi pengelolaan BMN. Underlying asset berupa BMN yang akan digunakan dalam penerbitan SBSN disyaratkan dalam kondisi bersih dari sengketa kepemilikan (clean) dan memiliki dokumen pendukung yang lengkap (clear) seperti bukti kepemilikan, dll. Persyaratan ini telah mendorong Kementerian/Lembaga untuk menyediakan kelengkapan administrasi tersebut, sehingga BMN berstatus clean and clear. Penggunaan BMN untuk underlying asset saat telah menggerakkan instansi Pemerintah untuk melakukan tertib administrasi dan pengelolaan aset-aset yang dimilikinya. Secara makro, hal ini akan memperkuat posisi akuntabilitas aset-aset yang dimiliki oleh negara. Pemanfaatan BMN ini juga mendorong Kementerian Keuangan untuk melakukan penilaian kembali terhadap aset negara, sehingga benar-benar diketahui harga riil dari aset negara tersebut. Adanya revaluasi asset tersebut terbukti meningkatkan nilai aset yang dimiliki oleh Pemerintah.

d. Mendorong tertib pengelolaan proyek infrastruktur Pemerintah

Demikian halnya dalam pengelolaan proyek infrastruktur oleh Kementerian/Lembaga, dengan dijadikan sebagai underlying asset pengelolaan proyek didorong menjadi lebih tertib terutama dalam hal progress pelaksanaan proyek dan penarikan dana sesuai yang direncanakan. Penyelesaian proyek sesuai dengan waktunya merupakan persyaratan syariah sebagaimana diatur dalam struktur akad yang digunakan. Penyelesaian proyek yang tidak tepat waktu menimbulkan ketidaksesuaian dengan kontrak yang telah diatur, sehingga harus dicegah agar tidak menimbulkan konsekuensi hukum yang lebih kompleks.

e. Menambah alternatif instrumen investasi bagi masyarakat

Seiring dengan perkembangan ekonomi, industri keuangan maupun non keuangan serta individu masyarkat Indonesia, tentu memerlukan instrumen investasi untuk meningkatkan nilai aset yang mereka miliki. Dengan adanya penerbitan SBSN akan memberikan tambahan instrumen investasi bagi pihak-pihak yang memiliki surplus dana. SBSN menjadi sangat menarik karena dijamin pembayaran imbalan mauun pokok investasinya oleh Pemerintah, sehingga dapat dikatakan sebagai instrumen investasi bebas risiko (zero risk). Selain bebas risiko, berinvestasi pada SBSN saat ini dianggap lebih menguntungkan bila dibandingkan dengan instrumen investasi yang memiliki fitur yang hampir sama, misalnya deposito. Hal ini dikarenakan, SBSN biasanya memberikan imbal hasil yang lebih menguntungkan bila dibandingkan dengan instrumen deposito yang diterbitkan oleh BUMN. Dengan diterbitkannya SBSN untuk investor ritel atau perorangan, secara tidk langsung juga telah mendukung pengembangan keuangan inklusif. Adanya SBSN untuk investor perorangan, misalnya Sukuk Negara Ritel dan Sukuk Negara Tabungan, telah memberikan kemudahan kepada masyarakat untuk ikut berinvestasi dan mengambangkan aset yang mereka miliki.

f. Membantu BI dalam melakukan Open Market Operation (OMO)

Dalam rangka menjaga tingkat inflasi (inflation targeting) otoritas moneter (BI) melakukan beberapa kebijakan diantaranya adalah mengendalikan jumlah uang beredar di masyarakat. Biasanya BI melakukan operasi pasar terbuka (open market operation/OMO) dengan cara mengurangi atau menambah jumlah uang beredar. Untuk melakukan OMO tersebut BI memerlukan beberapa instrumen yang dapat digunakan untuk memengaruhi jumlah uang yang beredar. Saat ini, dengan tersedianya SBSN dalam tenor pendek (6 bulan) BI dapat memanfaatkan instrumen tersebut untuk melakukan OMO. BI dapat memperoleh SBSN jangka pendek dengan membeli di pasar perdana pada saat pemerintah mengadakan lelang SBSN bertenor pendek atau disebut sebagai Surat Perbendaharaan Negara-Syariah (SPN-S). Ketika OMO dilaksanakan BI dapat menggunakan SPN$\mathrm{S}$ untuk memengaruhi jumlah uang beredar dengan memperjualbelikannya kepada industri keuangan terutama perbankan. Ketika BI ingin mengurangi jumlah uang beredar, maka BI dapat menjual SPN-S ke perbankan sehingga uang yang beredar masuk ke BI. Demikian sebaliknya ketika BI ingin menambah jumlah uang beredar BI dapat membeli kembali SPN-S yang ada di 
industri keuangan, sehingga uang akan mengalir ke masyarakat. Penggunaan SPN-S ini digunakan terutama ketika BI akan mengadakan OMO dengan partner industri keuangan syariah. Hal ini dikarenakan industri keuangan syariah hanya dapat menerima instrumen keuangan syariah saja sebagai portofolio aset mereka (Hariyanto, 2018).

Manfaat lain juga disampaikan oleh Manab dan Sujianto yaitu: (Manab \& Sujianto, 2016):

1) Memperluas basis sumber pembiayaan anggaran Negara,

2) Memperkaya instrumen pembiayaan fiskal,

3) Memperluas dan mendiversifikasi basis investor SBN,

4) Mendorong pertumbuhan dan pengembangan pasar keuangan syariah didalam negeri,

5) Mengembangkan alternatif instrumen investasi,

6) Menciptakan benchmark di pasar keuangan syariah,

7) Mengoptimalkan pemanfaatan Barang Milik Negara dan mendorong tertib administrasi pengelolaan Barang Milik Negara.

Selain memberikan manfaat kepada Negara, sukuk juga memberikan manfaat kepada investor yang melakukan investasi instrumen ini, yaitu:

1) Memberikan imbalan yang dibayarkan secara periodik,

2) Pembayaran imbalan dan nilai nominal dijamin oleh Negara,

3) Dapat diperjual belikan dipasar sekunder pada hargapasar,

4) Terdapat potensi capital gain bagi sukuk holders,

5) Instrumen investasi yang sesuai dengan prinsip syariah.

\section{KESIMPULAN}

Penerbitan Sukuk Negara dari tahun ke tahun terus mengalami peningkatan, sesuai dengan perkembangan dan strategi yang diterapkan dalam APBN. Pemerintah Indonesia telah mengeluarkan Sukuk Ritel (SR) yaitu SR 001, SR 002, SR 003, SR 004, SR 005, SR 006, SR 007, SR 008, SR 009, SR 010, SR 011, SR 012, dan SR 013. Penerbitan Sukuk Surat Berharga Syariah Negara (SBSN) sangat bermanfaat bagi Indonesia dalam hal menambah pendapatan APBN. Penambahan biaya APBN digunakan untuk pembangunan proyek dari sektor energi, telekomunikasi, perhubungan, pertanian, industri manufaktur, dan perumahan. Tak hanya itu, manfaat Sukuk juga mendorong pengembangan pasar keuangan syariah, menciptakan branchmark di pasar keuangan syariah, diversifikasi basis investor, mengembangkan alternatif instrumen investasi, mengoptimalkan pemanfaatan barang milik negara atau perusahaan, dan memanfaatkan dana-dana masyarakat yang belum terjaring oleh sistem obligasi dan perbankan konvensional.

\section{REFERENSI}

Anik, A., \& Prastiwi, I. E. (2017). Pengembangan Instrumen Sukuk Dalam Medukung Pembangunan Infratruktur. Jurnal Ilmiah Ekonomi Islam, 3(03), 173-180. https://doi.org/10.29040/jiei.v3i03.129

Beik, I. S. (2011). Memperkuat Peran Sukuk Negara Dalam Pembangunan Ekonomi Indonesia. $A L$ INFAQ, 2(2).

Direktorat Jenderal, Pengelolaan Pembiayaan dan Risiko, \& Kementerian Keuangan. (n.d.). Surat Berharga Syariah Negara. Retrieved September 23, 2020, from https://www.djppr.kemenkeu.go.id/page/load/16 56

Elba Damhuri. (2018, November 13). Mengukur Seberapa Besar Manfaat Sukuk. Republika Online. https://republika.co.id/share/pi40kr440

Hariyanto, E. (2018). PERAN STRATEGIS SUKUK NEGARA. 3.

Hastuti, E. S. (2018). SUKUK TABUNGAN: INVESTASI SYARIAH PENDORONG PEMBANGUNAN EKONOMI INKLUSIF. Jurnal Jurisprudence, 7(2), 114-122. https://doi.org/10.23917/jurisprudence.v7i2.409 6

Iskandar, A. (2014). Pengaruh Penerbitan Sukuk Negara Sebagai Pembiayaan Defisit Fiskal dan Kondisi Ekonomi Makro Terhadap Perkembangan Perbankan Syariah di Indonesia (The Effect of Sovereign Sukuk Issuance as State Fiscal Funding and Macroeconomics on The Islamic Banking Growth in Indonesia). Jurnal of Info Artha Sekolah Tinggi Akuntansi Negara (STAN), 1-21.

Manab, H. A., \& Sujianto, A. E. (2016). Pengaruh Stabilitas Ekonomi Makro Terhadap Penerbitan Sukuk Negara di Indonesia, Malaysia dan Brunei Darussalam.

Naili Rahmawati. (2015). Manajemen Investasi Syariah. CV. Sanabil. 
Jurnal Ilmiah Ekonomi Islam, 6(03), 2020, 427

Peristiwo, H. (2016). ANALISIS MINAT INVESTOR DI KOTA SERANG TERHADAP INVESTASI SYARIAH PADA PASAR MODAL SYARIAH. ISLAMICONOMIC: Jurnal Ekonomi Islam, 7(1). https://doi.org/10.32678/ijei.v7i1.7

Presiden Republik Indonesia. (2008). UU 19 Tahun 2008 SBSN. LEMBARAN NEGARA REPUBLIK INDONESIA TAHUN 2008 NOMOR 70.

Ramadayanti, R. S., Mainata, D., \& Pratiwi, A. (2018). Peran Sukuk Negara dalam Pembiayaan Infrastruktur. Al-Tijary, 2(2), 155. https://doi.org/10.21093/at.v2i2.788
Sarwono, J. (2010). Pintar menulis karangan ilmiahkunci sukses dalam menulis ilmiah. Penerbit Andi.

Sudarsono, H. (2009). Peran Obligasi Syariah (Sukuk) bagi Pembanguan Nasional. Jurnal Aplikasi Bisnis, 7(12), 1053-1072.

Sugiyono, S. (2016). Metode Penelitian Kuantitatif, Kualitatif dan $R \& D$. PT Alfabet.

Sunarsih, S. (2008). Potensi Obligasi Syariah Sebagai Sumber Pendanaan Jangka Menengah dan Panjang bagi Perusahaan di Indonesia. AsySyir'ah: Jurnal Ilmu Syari'ah Dan Hukum, 42(1), 55-83.

Umam, K. (2013). Pasar Modal Syariah dan Praktik Pasar Modal Syariah. Bandung: Pustaka Setia. 